\title{
Credit Markets Development and Economic Growth: Theory and Evidence
}

\author{
Seifallah Sassi \\ Laboratory of Applied Economics and Finance, University of Carthage, Tunis, Tunisia \\ Email: seifallah.sassi@yahoo.fr
}

Received 20 June 2014; revised 7 September 2014; accepted 1 November 2014

Copyright (C) 2014 by author and Scientific Research Publishing Inc.

This work is licensed under the Creative Commons Attribution International License (CC BY). http://creativecommons.org/licenses/by/4.0/

c) (†) Open Access

\begin{abstract}
The purpose of this paper is to study jointly the effects of consumer credit market and investment credit market on economic growth. We introduce consumer credit market in Schumpeterian framework. Under credit market imperfections, our model predicts a negative effect of the development of consumer credit market and a positive effect of the development of investment credit market on economic growth. We next confront the model on a panel of 27 European's countries over the period 1995-2012. Using GMM dynamic panel data estimation, empirical results confirm our theoretical predictions. Credit composition may give explanation of the ambiguous credit-growth nexus and its heterogeneity across country.
\end{abstract}

\section{Keywords}

Credit Markets Development, Economic Growth, Consumer Credit, Investment Credit, Panel Data

\section{Introduction}

Major theoretical literature on financial development and economic growth supports the argument that credit market development has a positive effect on economic growth by enhancing capital accumulation and technological changes. A general consensus exists among economists that a well-developed credit system spurs economic growth by improving resources allocation channeled into investment, reducing information and transaction costs and allowing risk management to finance riskier but more productive investments and innovations. However, recent empirical studies don't support the finance-led growth hypothesis. This finding is considered as a puzzle for theories underpinning for the importance of credit market development for growth. This conflicting finding is proved by a number of recent papers.

Using GMM dynamic panel data estimation and Pooled Mean Group estimator, with two indicators of financial development, Favara (2003) [1] found no evidence on the impact of financial development on growth pat- 
tern and concluded that the conventional positive causality of financial development on economic growth was based on average effects which vary varied according to the sample and the period considered and the techniques used.

Loayza and Rancière (2006) [2] have provided evidence, on a sample of 75 countries during the period 19602000, that the impact of private domestic credit on economic growth is significantly positive in the long run but significantly negative in the short-term.

Ben Naceur and Ghazouani (2007) [3] and Saci et al. (2009) [4], used dynamic panel models on respectively, 11 MENA countries and 30 developing countries, and find evidence of a positive effect of stock markets development but a meaningful negative effect of bank development on growth.

In presence market imperfections, credit market development isn't able to lead the expected effect on growth. Credit market imperfections are mainly asymmetric information, adverse selection, high information, transaction, and monitoring costs and credit market repression in the form of borrowing constraints imposed by government interventions. Asymmetric information and high transaction costs led to interlinkage of markets which reduced the degree of competition in the economy (Braverman and Stiglitz, 1982 [5]). Bernanke, Gertler and Gilchrist (1999) [6] showed the imperfections add persistence to the macroeconomic dynamics. Credit constraints have distributional impacts on the business cycles and thereby volatility and growth Aghion and Banerjee (2005) [7]. A particularly important consequence of such imperfections is the existence of credit rationing. With rationed credit markets, the business cycle is amplified and the long-term investment becomes procyclical. Thus, these imperfections seem to have serious implications on the growth path in developing and developed countries.

Empirical studies use generally credit to private sector as proxy of credit market development and don't distinguish the specific effect of each credit market, consumer and investment credit markets, on economic growth. Certainly, investment and consumer credit have different effects on economic development and a specific transmission channel. Schumpeter (1911) [8] believed that the credit to enterprise was the necessary premise for the realization of the innovative processes. Jappelli and Pagano (1994) [9] argued that alleviating credit constraints on households reduced the savings rate, with negative repercussions for economic growth. Galor and Zeira (1993) [10] provided evidence that consumer credit could affect positively economic growth only if it's invested in human capital and/or microenterprises. Using a dataset of 45 developed and developing countries, Beck, Büyükkarabacak, Rioja et Valev (2012) [11] found evidence that investment credit raised economic growth whereas household credit had no significant effect on real-economy performance. Dos Santos P. (2011) [12] was one of the pioneers who examined the distinctive transmission channel of investment and consumption credit using a Marxian framework. He showed that economies with higher relative share of consumption credit would generally suffer from a lower rate of net credit extension and higher levels of financial risk than comparable economies.

This paper aims to investigate this field in the attention to provide theoretical and empirical explanations to the credit-growth puzzle. To do so, we investigate the relationship between credit markets development and economic growth in the presence of financial markets imperfections. We introduced consumer credit market in the theoretical framework of Aghion, Howitt and Mayer Foulkes (2005) [13]; and we considered credit market imperfections in both, consumer and investment credit markets. The result is a Schumpeterian model with two period overlapping generations, in which each credit market has a specific effect on economic development. The model predicts that the development level of consumer credit market has a negative effect on convergence to the technology frontier thus on economic growth whereas the development level of investment credit market has a positive on growth. These causalities are maintained till the development level of credit market reaches the optimum; after that, credit markets development will have no effect on economic development. These predictions were tested and supported empirically using system GMM estimators of dynamic panel on cross-sectional data of 27 European countries during the period 1995-2012.

The paper is organized as follows. In Section 2, we develop the theoretical framework of Aghion et al. (2005) [13] by introducing consumer credit market in the model. Section 3 tests empirically the theoretical implications of the model using panel data of European countries. Section 4 is the conclusion.

\section{The Model}

We develop the two-period overlapping generations model of Aghion et al. (2005) [13]. The framework supposes that between $\mathrm{m}$ economies in the world, there are only exchanges of technological ideas. The population of each country $P$ is fixed and normalized to unity. Each generation is composed of two types of agents, lenders and borrowers. Borrowers are further divided into two groups as consumers and entrepreneurs who differ in 
their preferences. Each of the labor market, capital market, and the loans market is a competitive market.

\subsection{The General Sector}

There is one multi-purpose "general" good, produced according to the production function:

$$
Z_{t}=P^{1-a} \int_{0}^{1} A_{t}(i)^{1-a} x_{t}(i)^{a} \mathrm{~d} i, \quad(0<a<1)
$$

where $x_{t}(i)$ is the input of the latest version of intermediate good $i$ and $A_{t}(i)$ is the productivity parameter associated with it.

The general good is used for consumption and as input to product and develop the intermediate goods. Since the general good is produced under perfect competition, the price of an intermediate good will be:

$$
p_{t}(i)=a\left[x_{t}(i) / A_{t}(i)\right]^{a-1}
$$

\subsection{Intermediate Sectors}

If in an intermediate sector, there is a successful innovation, the productivity of this sector will equal the productivity at the world technology frontier $\bar{A}_{t}$ which grows with a positive constant rate. Therefore, the productivity of a sector $i$ evolve according:

$$
A_{t}(i)=\left\{\begin{array}{l}
\bar{A}_{t} \text { with probability } \mu_{t}(i) \\
A_{t-1}(i) \text { with probability } 1-\mu_{t}(i)
\end{array}\right.
$$

In each intermediate sector, there some people who are able to produce a new version of intermediate good for a unit cost equal to $\chi>1$. We assume that the market price of the last generation intermediate good will be $\chi$. So the quantity demanded will be:

$$
x_{t}(i)=(a / \chi)^{1 /(1-a)} A_{t}(i)
$$

An unsuccessful innovator will earn nothing and the profit of a successful innovator will be:

$$
\pi_{t}(i)=\pi \bar{A}_{t}
$$

where $\pi=(\chi-1)\left(\frac{a}{\chi}\right)^{1 /(1-a)}$

\subsection{Aggregate Behavior}

For notational convenience, “average productivity” is defined as:

$$
A_{t}=\int_{0}^{2} A_{t}(i) \mathrm{d} i
$$

Let's assume that at equilibrium the probability of innovation will be the same for all intermediate sector $\left(\mu_{t}(i)=\mu_{t}\right)$; so average productivity will be equal to:

$$
A_{t}=\mu_{t} \bar{A}_{t}+\left(1-\mu_{t}\right) A_{t-1}
$$

The technology gap is defined as: $a_{t}=A_{t} / \bar{A}_{t}$. This ratio evolves according:

$$
a_{t}=\mu_{t}+\frac{\left(1-\mu_{t}\right)}{(1+g)} a_{t-1}
$$

Therefore the production function (1) of the "general" good can expressed as:

$$
Z_{t}=\zeta A_{t}
$$

where où $\zeta=\left(\frac{a}{\chi}\right)^{a /(1-a)}$ 
Under perfect competition, the wage rate will be:

$$
w_{t}=(1-a) \zeta A_{t}
$$

\subsection{Innovation}

Let’s define R\&D investment function as:

$$
N_{t}=\tilde{n}\left(\mu_{t}\right) \bar{A}_{t}=\left(\eta \mu_{t}+\frac{\delta \mu_{t}^{2}}{2}\right) \bar{A}_{t} \text { où } \delta, \eta>0
$$

where $N_{t}$ is the quantity of general good that must be invested. Thus an entrepreneur who has invested $n \bar{A}_{t}$ in R\&D will innovate with probability equal to:

$$
\mu_{t}(n)=\left(\sqrt{\eta^{2}+2 \delta n}-\eta\right) / \delta
$$

And his expected net payoff is given as:

$$
\mu_{t} \pi \bar{A}_{t}-N t-1=\mu_{t} \beta \pi \bar{A}_{t}-\tilde{n}\left(\mu_{t}\right) \bar{A}_{t}
$$

\subsection{Credit Markets}

For analytical convenience, it is assumed that banks operate at no cost and they don't earn profit. Thus interest rates for lenders and borrows are the same and equal to $r_{t}$.

\subsubsection{Consumer Credit Market}

1) Consumer Credit Market Imperfections

To introduce credit market imperfections, we suppose that there are some dishonest agents who are able to sacrifice a proportion $\theta$ of their unit of labor to obtain a credit. If the loan is granted, this type of agents will miss repayment. In this case, the agent will spend the remainder of his labor endowment in the labor market and its future consumption will be equal to $\left[(1-\theta) w_{t}+q_{t}\right]$ where $q_{t}$ is the credit amount. On the other hand, if an honest agent chooses to spend all of his labor endowment in the labor market then deposits his wage rate at a bank; its future consumption will be equal to $\left(1+r_{t}\right) w_{t}=R_{t} w_{t}$.

Obviously, if $(1-\theta) w_{t}+q_{t} \geq R_{t} w_{t}$ or equivalently, if $q_{t} \geq R_{t} \omega_{t}-(1-\theta) \omega_{t} \equiv\left[R_{t}-(1-\theta)\right] \omega_{t} \equiv x w_{t}$

All consumers will apply for a loan then miss repayment if the credit is granted. So banks impose a natural credit constraint on consumers and set credit at fixed proportion $x$ of consumer wage rate.

We represent the development of Consumer Credit market by the cost parameter $x$. It follow that $x$ is an increasing function of interest rate $r_{t}$ and defraud cost $\theta$.

$$
x \equiv\left[R_{t}-(1-\theta)\right] \equiv\left(R_{t}+\theta-1\right) \equiv\left(r_{t}+\theta\right)
$$

This means that, in one hand, banks are able to supply more credit and take more risk by increasing interest rate $r_{t}$; and in the other hand, more $\theta$ is higher more credit market is developed and banks are able to supply more consumer loans.

2) Supply of Consumer Credit

Each consumer is endowed with one unit of labor in his first period of life. His wage rate $w_{t}$, given by Equation (9), is determined by competitive market. To consume in the second period of life, consumers deposits their wages rate at a bank. The utility function of a consumer is given as:

$$
U=\ln \left(C_{t, t}\right)+\beta \ln \left(C_{t, t+1}\right)
$$

where $C_{t, j}$ is the consumption of a consumer of generation $t$ in period $j$.

Since consumer has no endowment in his first period of life, his is obliged to apply for a credit. Thus, with no credit constraints, the optimal consumption is the solution of this system:

$$
\left\{\begin{array}{l}
\operatorname{Max} U=\ln U=\ln \left(C_{t, t}\right)+\beta \ln \left(C_{t, t+1}\right) \\
C_{t, t}+\frac{C_{t, t+1}}{R_{t}}=\frac{w_{t}}{R_{t}}
\end{array}\right.
$$


The optimal plan for consumers is to consume $C_{t, t}^{*}$ in his first period of life and to consume $C_{t, t+1}^{*}$ in his second period of life; where:

$$
\begin{gathered}
C_{t, t}^{*}=w_{t} /\left[(1+\beta) R_{t}\right] \\
C_{t, t+1}^{*}=\beta /(1+\beta) w_{t}
\end{gathered}
$$

From Equation (14), the credit size supplied at the first period equal to $w_{t} /\left[(1+\beta) R_{t}\right]$ and its repayment in the second period equal to $\beta w_{t} /(1+\beta)$ which is independent of the interest rate.

Therefore, under perfect credit market, the total optimal consumption for an agent:

$$
C_{t}^{*}=C_{t, t}+C_{t, t+1}=\frac{w_{t}}{(1+\beta) R_{t}}+\frac{\beta w_{t}}{(1+\beta)}=\frac{1+\beta R_{t}}{(1+\beta) R_{t}} w_{t}
$$

Now, under credit market imperfections, the credit granted, $x \omega_{t}$, is less than $w_{t} /\left[(1+\beta) R_{t}\right]$ equivalently $x<1 /\left[(1+\beta) R_{t}\right]$. Consumer borrows and consumes $C_{t, t}=x w_{t}$ in his first period of life and in his second period of life, he repay $R_{t} x w_{t}$ and consume $C_{t, t+1}=\left(1-R_{t} x\right) w_{t}$. Hence, under credit market imperfections, the total consumption for an agent equal to:

$$
C_{t}=x w_{t}+\left(1-R_{t} x\right) w_{t}=\left[1+x\left(1-R_{t}\right)\right] w_{t}
$$

Since $\left(1-R_{t}\right)<0$, the total consumption is a decreasing function of the development level of consumer credit market for $x<w_{t} /\left[(1+\beta) R_{t}\right]$. After this threshold, credit market development will have no effect on consumption which reaches the optimal level $C_{t}^{*}=\left(1+\beta R_{t}\right) w_{t} /(1+\beta) R_{t}$.

Therefore, the total consumption evolves according to:

$$
\left\{\begin{array}{l}
C_{t}=w_{t}+x\left(1-R_{t}\right) w_{t} \quad \text { when } \quad 0 \leq x<\frac{w_{t}}{(1+\beta) R_{t}} \\
C_{t}=\frac{1+\beta R_{t}}{(1+\beta) R_{t}} w_{t} \quad \text { when } \quad x \geq \frac{w_{t}}{(1+\beta) R_{t}}
\end{array}\right.
$$

The development level of consumer credit market $x$ has a negative effect on consumption till a threshold $1 / 2 R_{t}$ where the consumption reaches the optimum and after that the development of consumer credit market will have no effect on consumption level.

\subsubsection{Investment Credit Market}

1) Investment Credit Market Imperfections

Each entrepreneur is endowed with a wage rate at the end of his first period of life. To invest $N_{t}$ in an R\&D project, he must borrow $\left(N_{t}-w_{t}\right)$. Following Aghion, Howitt and Mayer-Foulkes (2005) [13] to introduce credit market imperfections, we suppose that, for a cost equal to $c N_{t}$ with $0<c<1$, an entrepreneur is able to defraud bank by hiding a successful innovation and miss credit repayment. So banks impose a natural credit constraint on entrepreneur and set credit at fixed proportion $v$ of his wage rate. Therefore, in equilibrium, entrepreneur can't borrow and invest more than a finite multiple of his wage rate:

$$
v w_{t}=\omega a_{t} \bar{A}_{t}
$$

where $v$ depends positively on the hiding cost $c$ and $\omega \equiv v(1-a) \zeta$.

The development level of investment credit market is represented by parameter $\omega$, such as a developed credit market is able to supply more credit and protect banks by increasing defraud cost $C$.

2) Supply of Investment Credit

In equilibrium and under perfect credit market, an entrepreneur will choose the probability $\mu^{* 1}$ which maximize his expected net payoff (12):

$$
\mu^{*}=(\beta \pi-\eta) / \delta
$$

The optimal R\&D investment equal to:

${ }^{1}$ It's supposed that $\eta<\beta \pi<\eta+\delta$ for that the probability $\mu^{*}$ will always lie strictly between 0 and 1 . 


$$
N_{t}^{*}=\tilde{n}\left(\mu^{*}\right) \bar{A}_{t}=n^{*} \bar{A}_{t}
$$

where $n^{*}=\left(\beta^{2} \pi^{2}-\eta^{2}\right) / 2 \delta$.

But with credit market imperfections, an entrepreneur is credit rationed if $a_{t} \bar{A}_{t}>n^{*} \bar{A}_{t}$, or equivalently, $\omega a_{t}>n^{*}$. Thus the amount invested is:

$$
N_{t}=\left[\left(\eta^{2} / 2 \delta\right)+\omega a_{t}\right] \bar{A}_{t}
$$

And he will innovate with probability:

$$
\mu_{t}\left(\omega a_{t}\right)=\left[\left(\sqrt{\eta^{2}+2 \delta\left(\omega a_{t}\right)}-\eta\right) / \delta\right]
$$

Therefore, the investment evolves according to:

$$
\left\{\begin{array}{lll}
N_{t}=\frac{\eta^{2}}{2 \delta} \bar{A}+\omega a_{t} \bar{A} & \text { when } & 0 \leq \omega<\frac{\beta^{2} \pi^{2}-2 \eta^{2}}{2 \delta a_{t}} \\
N_{t}=N^{*}=\left(\frac{\beta^{2} \pi^{2}-\eta^{2}}{2 \delta}\right) \bar{A}_{t} & \text { when } & \omega \geq \frac{\beta^{2} \pi^{2}-2 \eta^{2}}{2 \delta a_{t}}
\end{array}\right.
$$

The development level of investment credit market $\omega$ has a positive effect on investment till a threshold $n^{*} \overline{A_{t}}$ where the investment reaches the optimum and after that the development of credit market will have no effect on investment level.

\subsection{Credit Markets Development and Economic Growth}

For closed economy without government, we can write the GDP per capita as:

$$
Y_{t}=C_{t}+N_{t}=\left[1+x\left(1-R_{t}\right)\right] w_{t}+\left(\frac{\eta^{2}}{2 \delta}+\omega a_{t}\right) \bar{A}_{t}
$$

Therefore GDP per capita is a decreasing function of the development level of consumer $x$ credit market and an increasing function of the development level of investment credit market $\omega$ till that consumption and investment reach the optimum; and after that GDP per capita will grows with a constant rate $g$ the same as the technology frontier $\bar{A}_{t}$.

\section{Empirical Evidence}

\subsection{Methodology}

To test our theoretical model, we use a second-order Taylor expansion to approximate $G_{t}=Y_{t+1} / Y_{t}$ in the neighborhood of the technology frontier ${ }^{2}$. Following Aghion, Howitt and Mayer Foulkes (2005) [13], we omit pure quadratic terms and we assume that there is just one leader, labeled country 1.

Our theoretical model is approximated by the following growth regression:

$$
g_{i t}-g_{1 t}=\beta_{0}+\beta_{1}\left(y_{i t}-y_{1 t}\right)+\beta_{2} \mathrm{CC}_{i t}+\beta_{3} \mathrm{CI}_{i t}+\beta_{4} X_{i t}+\mu_{i}+\lambda_{t}+\varepsilon_{i t}
$$

where $g$ denotes the growth rate of per-capita GDP, $y$ the initial log of per-capita GDP, CC the log of consumer credit, CI the log of investment credit and $X$ a set of control variables. Control variables used in our econometric investigation are GC the log of government consumption to GDP, INF inflation rate and Trade the log of the ratio of exports plus imports to GDP. Country 1 is the technology leader.

Given the specification of Equation (23), our regression is considered as a dynamic panel model. So, efficient estimators are given through the generalized method of moments. Arellano and Bover (1995) [14] and Blundel

$$
\begin{aligned}
G(\omega, a, x) \cong\{ & G\left(\omega_{1}, a_{1}, x_{1}\right)+G_{\omega}^{1}\left(\omega-\omega_{1}\right)+G_{a}^{1}\left(a-a_{1}\right)+G_{x}^{1}\left(x-x_{1}\right)+\frac{1}{2} G_{\omega \omega}^{1}\left(\omega-\omega_{1}\right)^{2}+\frac{1}{2} G_{a a}^{1}\left(a-a_{1}\right)^{2} \\
& \left.+\frac{1}{2} G_{x x}^{1}\left(x-x_{1}\right)^{2}+G_{\omega o}^{1}\left(\omega-\omega_{1}\right)\left(a-a_{1}\right)+G_{x \omega}^{1}\left(x-x_{1}\right)\left(\omega-\omega_{1}\right)+G_{x a}^{1}\left(x-x_{1}\right)\left(a-a_{1}\right)\right\} .
\end{aligned}
$$


and Bond (1998) [15] shows that the system GMM estimator provide a more efficient estimator than the difference GMM estimator. The estimates were made by the one step and two step system GMM. In the one-step estimator, the error term $\varepsilon_{i t}$ is assumed to be independent and homoskedastic across countries and time. In the two-step estimator, the residuals of the first step are used to consistently estimate the variance-covariance matrix of the residuals, relaxing the homoskedasticity assumption. In the two-step System GMM, we adopt Windmeijer (2005) [16] small sample robust correction which makes a finite-sample adjustment for the two-step covariance matrix.

As a robustness check, we use data over five years instead of annual to prevent any biased estimates and to capture business cycle movements.

An important step that is relevant to the estimation of our model is to conduct M2 test, Sargan test, Hansen test and Kleibergen-Paap tests. The M2-test checks problem regarding the second-order serial autocorrelation of the error terms. The sargan test verifies that the instruments used are not correlated with the residuals. The Hansen test and the Kleibergen-Paap test provides statistics for weak instruments due to an over-identification and under-identification, respectively.

\subsection{Data}

Our model is tested a balanced sample of 27 European's countries ${ }^{3}$ over the period 1995-2012. Germany is considered as the leader of the 27 European's countries in our sample. Disaggregated data on credit were extracted from Europeen Credit Research Institute Database. The WDI-World Bank database is the source for other macroeconomic variables. Table A1 and Table A2 in Appendix report respectively summary statistics and empirical correlations between variables.

The dataset shows that growth rate of GDP per capita is negatively correlated with consumer credit and positively correlated with investment credit. Macroeconomic indicators have the expected correlation sign with the economic growth: growth rate of GDP per capita is negatively correlated with government consumption as inflation and positively correlated with trade.

\subsection{Empirical Results}

The results from estimating Equation (23) are reported in Table 1. System GMM regressions on annual data are reported in columns (1) and (2). These results confirms theoretical predictions and show that consumer credit has a significant negative effect on convergence to the leader growth rate and investment credit promotes positively the convergence at 5\% significance level for the two specifications, one step and two step system GMM. In regression (3) and (4), we use data over five years instead of annual as a robustness check and to capture business cycle movements. Columns (3) and (4) confirm our main findings: consumer credit affects negatively and significantly the catch-up of technological frontier however investment credit has a positive effect.

Our findings give an explanation of the ambiguous credit-growth nexus in empirical literature since its uses aggregate credit to private sector as proxy of credit market development. Empirical studies must consider credit composition and study a distinctive effect of each market. In developed and developing countries, consumer credit market continues has an "explosive” trend while investment credit market show weak growth rate.

Theory provide evidence about the positive effect of investment credit on economic growth through capital accumulation, productivity growth and resource allocation but the effect of consumer credit on economic growth is ambiguous. Using a sample of 25 countries, Jappelli and Pagano (1994) [9] provide evidence that the development of consumer credit market has a negative effect on economic growth through reducing saving rate. Galor and Zeira (1993) [10] and De Gregorio (1996) [17] show that consumer credit affect positively economic growth only if it's invested in human capital and/or microenterprises.

Furthermore, our findings provide also a clarification of theheterogeneity of credit-growth nexus across country. This can be explained by the disparity of the composition of credit across country and sample.

Our results shows that a negative relationship between relative growth rate and the initial GDP per capita relative to the leader. Thus the hypothesis of conditional convergence is validated. This concept assumes that each country converges to its own long-run equilibrium path and record a high growth rate when it's far from the path.

\footnotetext{
${ }^{3}$ Austria, Belgium, Bulgaria, Cyprus, Czech Republic, Denmark, Estonia, Finland, France, Germany, Greece, Hungary, Ireland, Italy, Latvia, Lithuania, Luxembourg, Malta, Netherlands, Poland, Portugal, Romania, Slovak Republic, Slovenia, Spain, Sweden, United Kingdom.
} 
Table 1. Dynamic panel-data estimation dependent variable: relative growth rate to the leader $g_{i t}-g_{1 t}$.

\begin{tabular}{|c|c|c|c|c|}
\hline \multirow{3}{*}{ Regressions } & \multicolumn{2}{|c|}{ Annual Data } & \multicolumn{2}{|c|}{ Data over Five Years } \\
\hline & $\begin{array}{c}\text { One Step } \\
\text { System GMM }\end{array}$ & $\begin{array}{c}\text { Two Step } \\
\text { System GMM }\end{array}$ & $\begin{array}{c}\text { One Step } \\
\text { System GMM }\end{array}$ & $\begin{array}{c}\text { Two Step } \\
\text { System GMM }\end{array}$ \\
\hline & $(1)$ & $(2)$ & (3) & (4) \\
\hline \multirow[t]{2}{*}{ Relative Initial Income to the Leader } & $-0.051^{* *}$ & $-0.048^{*}$ & $-0.017^{* *}$ & $-0.019^{*}$ \\
\hline & $(-2.00)$ & $(-1.81)$ & $(-1.96)$ & $(-1.69)$ \\
\hline \multirow[t]{2}{*}{ Consumer Credit } & $-0.094^{* *}$ & $-0.085^{* * *}$ & $-0.026^{* *}$ & $-0.039^{* * *}$ \\
\hline & $(-2.29)$ & $(-3.56)$ & $(-2.24)$ & $(-2.76)$ \\
\hline \multirow[t]{2}{*}{ Investment Credit } & $0.102^{* *}$ & $0.115^{* *}$ & $0.076^{* *}$ & $0.098^{* *}$ \\
\hline & $(2.4)$ & (1.99) & $(2.34)$ & $(2.15)$ \\
\hline \multirow[t]{2}{*}{ Government Consumption } & $0.096^{* * *}$ & $0.115^{* * *}$ & $0.031^{* *}$ & $0.058^{* *}$ \\
\hline & $(2.92)$ & $(3.17)$ & $(2.4)$ & $(2.28)$ \\
\hline \multirow[t]{2}{*}{ Inflation Rate } & -0.031 & $-0.019^{*}$ & $-0.001^{*}$ & $-0.003^{* *}$ \\
\hline & $(-1.65)$ & $(-1.85)$ & $(-1.76)$ & $(-1.99)$ \\
\hline \multirow[t]{2}{*}{ Trade Openness } & $0.078^{* * *}$ & $0.064^{* *}$ & $0.022^{* *}$ & 0.027 \\
\hline & $(2.66)$ & $(2.02)$ & $(2.55)$ & $(1.58)$ \\
\hline \multirow[t]{2}{*}{ Constant } & $-0.528^{* * *}$ & $-0.372^{* *}$ & $-0.756^{* * *}$ & $-0.694^{* * *}$ \\
\hline & $(-2.7)$ & $(-2.19)$ & $(-2.82)$ & $(-2.96)$ \\
\hline Wald Test & 0.000 & 0.000 & 0.000 & 0.000 \\
\hline M2 Test & 0.425 & 0.536 & 0.730 & 0.662 \\
\hline Sargan Test & 0.439 & 0.477 & 0.610 & 0.626 \\
\hline Hansen Test & & 0.278 & & 0.335 \\
\hline Kleibergen-Paap Test & 0.002 & 0.002 & 0.006 & 0.006 \\
\hline Observations & 442 & 442 & 78 & 78 \\
\hline
\end{tabular}

T-Student are reported in parentheses. ${ }^{* * *},{ }^{* *}$, and ${ }^{*}$ indicate significance levels at 1,5 , and 10 percent, respectively. For the M2 test for autocorrelation, the null hypothesis is that the errors in the first-difference regression exhibit no second-order serial correlation. For Sargan test, the null hypothesis is that the instruments used are not correlated with the residuals. For the Kleibergen-Paap test of under-identification, the null hypothesis is that the instruments used are potentially weak. For Wald Test, M2 test, Sargan Test, Hansen Test and the Kleibergen-Paap test the p-values are reported.

The control variables have the expected sign and are tightly estimated. The harmful effect of inflation rate on economic growth is confirmed by a negative and significant sign in the two specifications of the GMM estimator. Government consumption has a positive and significant effect on economic growth at least at 5\% level in all specification. This finding proves that public consumptions in European countries are spending mainly in investment and infrastructure which improve economic growth (Kneller, Bleaney, and Gemmell, 1999 [18]). The trade openness is positively correlated to economic growth. Trade openness boosts economic growth by facilitating the exchange of goods and services and by improving capital allocation efficiency.

Our results are robust: M2 confirms the absence of a second-order serial correlation of the residuals in the differenced regression. The Sargan test confirms no correlation between the used instruments and the residuals. Finally the Hansen and the Kleibergen-Paap test do not detect any problem of over-identifications and underidentifications restrictions and confirm the validity of variables in differences and in levels as instruments in system GMM.

\section{Conclusions}

This paper attempts to distinguish the specific effect of consumer and investment credit markets on economic growth. We develop the theoretical framework of Aghion et al. (2005) [13] by introducing consumer credit market in the model and by considering credit market imperfections in both, consumer and investment credit markets.

The model predicts that the development level of investment credit market affects positively convergence to 
the technology frontier, however, consumer credit market development affects negatively convergence. On a balanced sample of 27 European's countries over the period 1995-2012, estimations were conducted using system GMM on annual data and data over five years. Empirical results produce evidence to support our predictions: Credit market promotes economic growth by lending to productive enterprises whereas consumer credit has a significant negative effect on real-economy performance. Our findings provide a missing piece of the credit-growth puzzle. The positive effect of investment credit market is dampening by the reverse relationship between consumer credit market and economic growth.

Banks must control the credit composition and the growth rate of the relative share of consumer credit. The increase of consumer credit induced a decline in the trade balance (Büyükkarabacak \& Krause, 2009 [19]) and a high level of financial volatility (Büyükkarabacak \& Valev, 2010 [20]).

\section{References}

[1] Favara, G. (2003) An Empirical Reassessment of the Relationship between Finance and Growth. International Monetary Fund Working Paper Series, 1-46.

[2] Loayza, N.V. and Ranciere, R. (2006) Financial Development, Financial Fragility, and Growth. Journal of Money, Credit and Banking, 38, 1051-1076. http://dx.doi.org/10.1353/mcb.2006.0060

[3] Ben Naceur, S. and Ghazouani S. (2007) Stock Markets, Banks and Growth in Some Mena Region Countries. Research in International Business and Finance, 21, 297-315. http://dx.doi.org/10.1016/j.ribaf.2006.05.002

[4] Saci, K., Giorgioni, G. and Holden, K. (2009) Does Financial Development Affect Growth? Applied Economics, 41, 1701-1707. http://dx.doi.org/10.1080/00036840701335538

[5] Braverman, A. and Stiglitz, J. (1982) Sharecropping and the Interlinking of Agrarian Markets. American Economic Review, 72, 695-715.

[6] Bernanke, B.S., Gertler, M. and Gilchrist, S. (1999) The Financial Accelerator in a Quantitative Business Cycle Framework. In: Taylor, J.B. and Woodford, M., Eds., Handbook of Macroeconomics, 1341-1393.

[7] Aghion, P. and Banerjee, A. (2005) Volatility and Growth. Oxford University Press, Oxford. http://dx.doi.org/10.1093/acprof:oso/9780199248612.001.0001

[8] Schumpeter, J.A. (1911) The Theory of Economic Development. Cambridge.

[9] Jappelli, T. and Pagano, M. (1994) Saving, Growth, and Liquidity Constraints. Quarterly Journal of Economics, 106, 83-109. http://dx.doi.org/10.2307/2118429

[10] Galor, O. and Zeira, J. (1993) Income Distribution and Macroeconomics. Review of Economic Studies, 60, 35-52. http://dx.doi.org/10.2307/2297811

[11] Beck, T., Büyükkarabacak, B., Rioja, F. and Valev, N. (2012) Who Gets the Credit? And Does It Matter? Household vs. Firm Lending across Countries. The B.E. Journal of Macroeconomics, 12, 1-46.

[12] Dos Santos, P. (2011) Production and Consumption Credit in a Continuous-Time Model of the Circuit of Capital. Research on Money and Finance, Discussion Paper No. 28.

[13] Aghion, P., Howitt, P. and Mayer-Foulkes, D. (2005) The Effect of Financial Development on Convergence: Theory and Evidence. Quarterly Journal of Economics, 120, 173-222.

[14] Arellano, M. and Bover, O. (1995) Another Look at the Instrumental Variable Estimation of Error-Components Models. Journal of Econometrics, 68, 29-51. http://dx.doi.org/10.1016/0304-4076(94)01642-D

[15] Blundell, R. and Bond, S. (1998) Initial Conditions and Moment Restrictions in Dynamic Panel Data Models. Journal of Econometrics, 87, 115-143. http://dx.doi.org/10.1016/S0304-4076(98)00009-8

[16] Windmeijer, F. (2005) A Finite Sample Correction for the Variance of Linear Efficient Two-Step GMM Estimators. Journal of Econometrics, 126, 25-51. http://dx.doi.org/10.1016/j.jeconom.2004.02.005

[17] De Gregorio, J. (1996) Borrowing Constraints, Human Capital Accumulation and Growth. Journal of Monetary Economics, 37, 49-71. http://dx.doi.org/10.1016/0304-3932(95)01234-6

[18] Kneller, R., Bleaney, M. and Gemmell, N. (1999) Fiscal Policy and Growth: Evidence from OECD Countries. Journal of Public Economics, 74, 171-190. http://dx.doi.org/10.1016/S0047-2727(99)00022-5

[19] Büyükkarabacak, B. and Krause, S. (2009) Studying the Effects of Household and Firm Credit on the Trade Balance: The Composition of Funds Matters. Economic Inquiry, 47, 653-666. http://dx.doi.org/10.1111/j.1465-7295.2008.00173.x

[20] Büyükkarabacak, B. and Valev, N.T. (2010) The Role of Household and Business Credit in Banking Crises. Journal of Banking and Finance, 34, 1247-1256. http://dx.doi.org/10.1016/j.jbankfin.2009.11.022 


\section{Appendix}

Table A1. Summary statistics.

\begin{tabular}{clccccc}
\hline Variable & Variable & Obs & Mean & Std. Dev & Min & Max \\
\hline$g$ & Annual growth of per capita real GDP & 486 & 2.377 & 3.734 & -17.545 & 14.933 \\
$y$ & income per capita (constant US \$2000) & 486 & 24402 & 16630 & 1373 & 87716 \\
CC & Consumer credit (\% GDP) & 486 & 0.446 & 0.306 & 0.004 & 1.407 \\
CI & Investment credit (\% GDP) & 486 & 0.320 & 0.204 & 0.035 & 1.355 \\
GC & Government consumption (\% GDP) & 486 & 0.198 & 0.511 & 0.069 & 0.3 \\
Trade & Total amount of exports and imports (\% GDP) & 486 & 1.076 & 0.528 & 0.442 & 3.335 \\
INF & Increasing rate of consumer price index over 1-year period (\%) & 486 & 0.071 & 0.49 & -0.044 & 10.584 \\
\hline
\end{tabular}

Table A2. Pairwise correlation matrix.

\begin{tabular}{cccccccc}
\hline & $g$ & $y$ & CC & CI & GC & Trade & INF \\
$g$ & 1 & & & & & & \\
$y$ & -0.2641 & 1 & & & & & \\
CC & -0.2562 & 0.7288 & 1 & & & & \\
CI & 0.2706 & 0.5957 & 0.7595 & 1 & & & \\
GC & -0.1616 & 0.2749 & 0.3673 & 0.3313 & 1 & & \\
Trade & 0.0844 & 0.3152 & -0.0898 & 0.0303 & -0.0883 & 1 & 1 \\
INF & -0.0524 & -0.1251 & -0.5693 & -0.4552 & -0.1481 & -0.0088 & \\
\hline
\end{tabular}


Scientific Research Publishing (SCIRP) is one of the largest Open Access journal publishers. It is currently publishing more than 200 open access, online, peer-reviewed journals covering a wide range of academic disciplines. SCIRP serves the worldwide academic communities and contributes to the progress and application of science with its publication.

Other selected journals from SCIRP are listed as below. Submit your manuscript to us via either submit@scirp.org or Online Submission Portal.
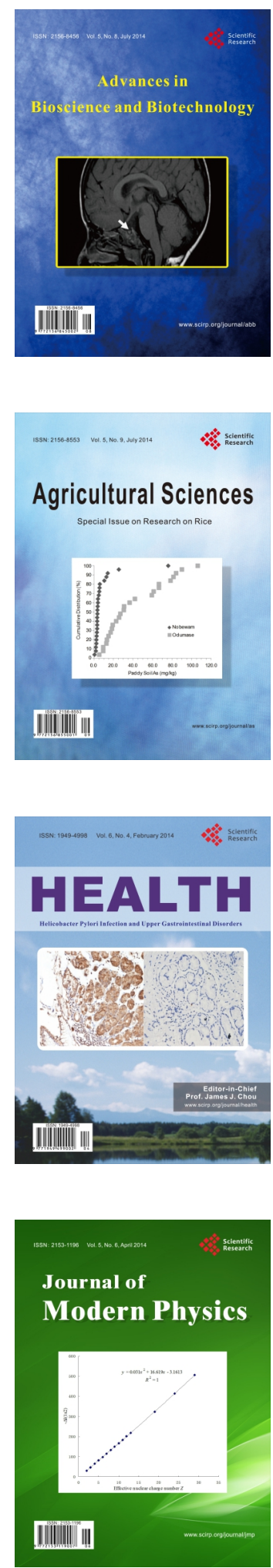
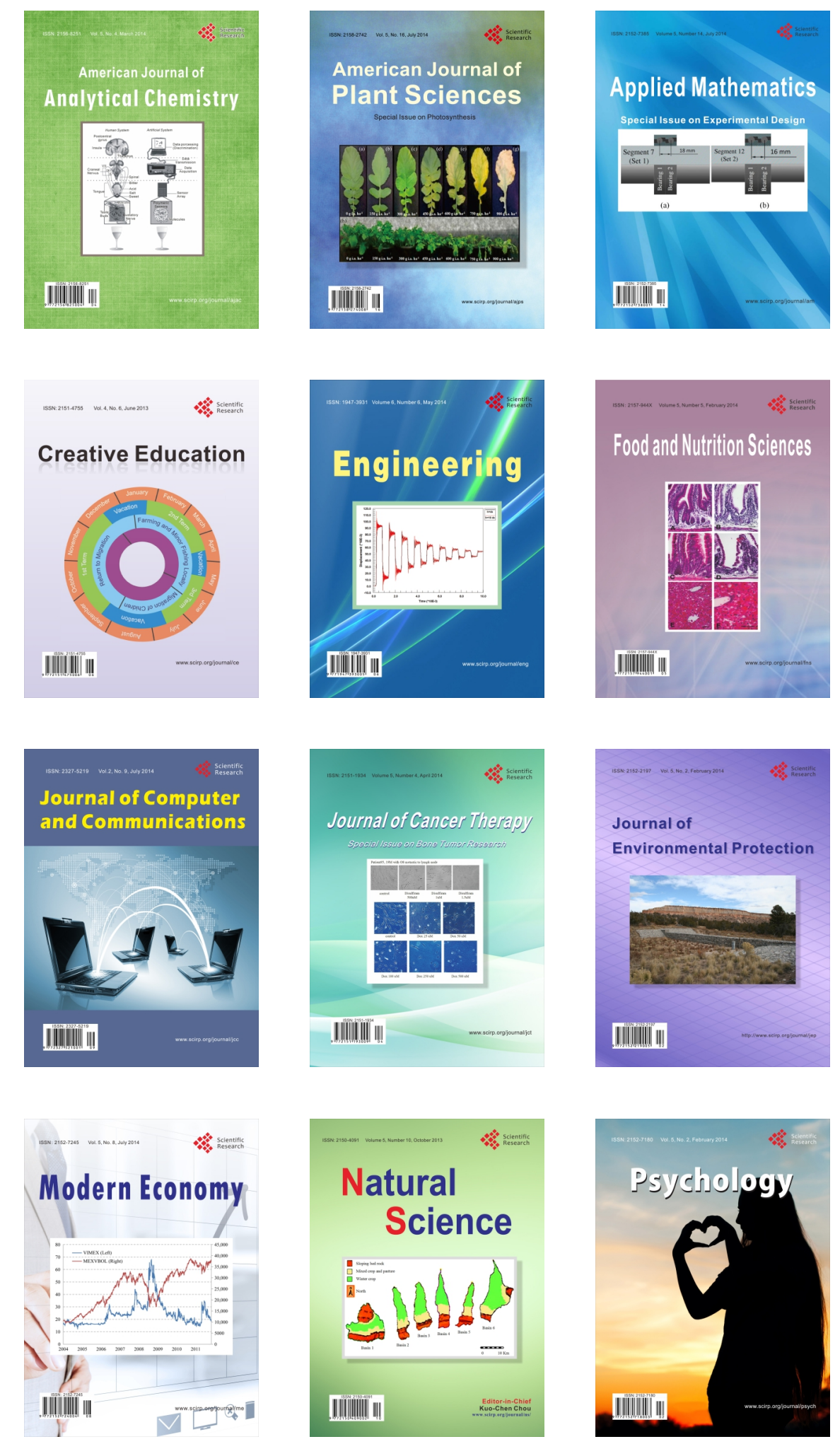